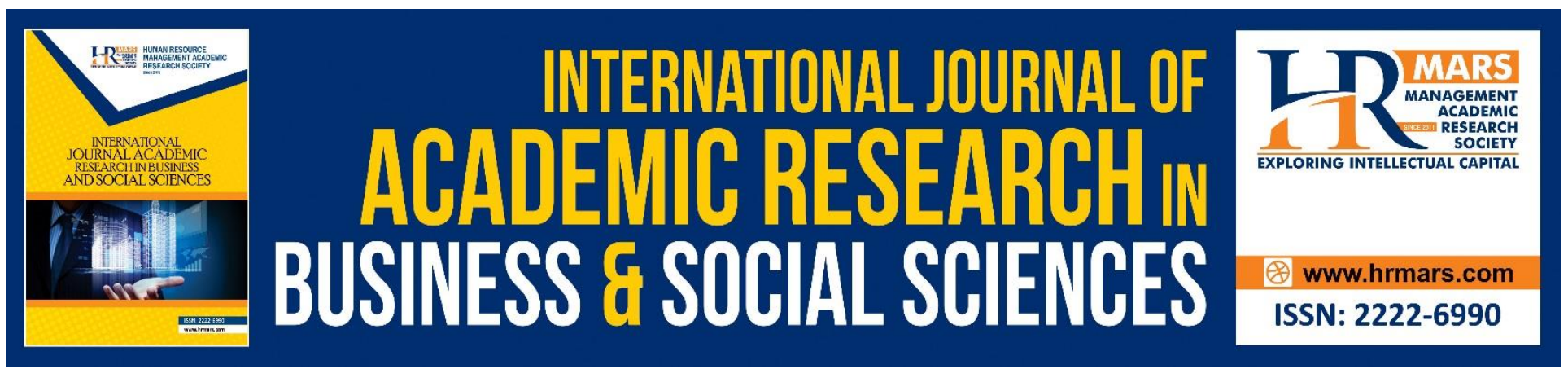

\title{
An Evaluation of the Impact of Remuneration on Employee Attitude and Performance in Organizations
}

Mohammed Nashwan Alwaki

To Link this Article: http://dx.doi.org/10.6007/IJARBSS/v8-i7/4383

DOI: $\quad 10.6007 /$ IJARBSS/v8-i7/4383

Received: 02 June 2018, Revised: 19 June 2018, Accepted: 29 June 2018

Published Online: 18 July 2018

In-Text Citation: (Alwaki, 2018)

To Cite this Article: Alwaki, M. N. (2018). An Evaluation of the Impact of Remuneration on Employee Attitude and Performance in Organizations. International Journal of Academic Research in Business and Social Sciences, $8(7), 410-420$.

Copyright: (C) 2018 The Author(s)

Published by Human Resource Management Academic Research Society (www.hrmars.com)

This article is published under the Creative Commons Attribution (CC BY 4.0) license. Anyone may reproduce, distribute, translate and create derivative works of this article (for both commercial and non-commercial purposes), subject to full attribution to the original publication and authors. The full terms of this license may be seen

at: http://creativecommons.org/licences/by/4.0/legalcode

Vol. 8, No. 7, July 2018, Pg. 410 - 420

http://hrmars.com/index.php/pages/detail/IJARBSS

JOURNAL HOMEPAGE

Full Terms \& Conditions of access and use can be found at http://hrmars.com/index.php/pages/detail/publication-ethics 


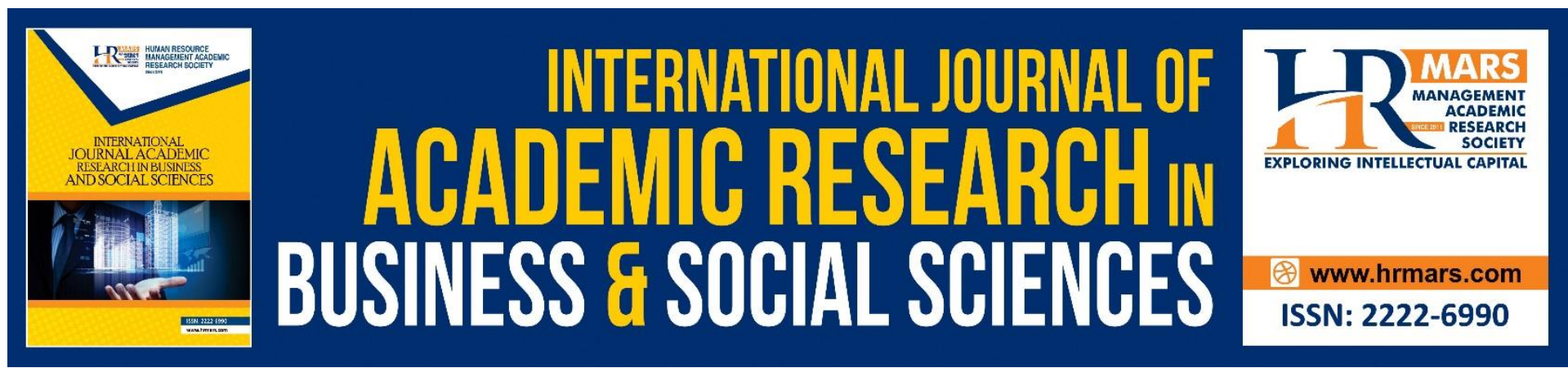

\title{
An Evaluation of the Impact of Remuneration on Employee Attitude and Performance in Organizations
}

\author{
Mohammed Nashwan Alwaki \\ Buraydah Community College- Qassim University- Saudi Arabia
}

\begin{abstract}
Everyone works for rewards, either in the form of pre-determined salaries, wages or some other benefits or any bonuses and remunerations for certain performance. Individuals seek for being compensated fairly and are only satisfied if they get the expected rewards resulting for their performance. Thus, current study investigates whether remuneration influences employees' performance through influencing employees' attitudes. Current study proposes that remuneration influences employees' performance while employees' attitude mediates the relationship between these two. A sample of 200 respondents from listed companies of Amman stock exchange is studied and implementing structural equation modeling it is found that in manufacturing organizations remuneration significantly influences employees' attitude that ultimately influences their performance. Hence, remuneration has significant influence on employees 'performance but by influencing their attitudes towards their jobs.
\end{abstract}

Keywords: Remuneration, Employee attitude, Employee performance, Textile Manufacturing and Clothing Sector, Amman Stock Exchange

\section{Introduction}

Pay for performance is one of the known practices of management. All compensation designs incorporate impetus and bonus plans keeping in mind the end goal to spur workers' performance by remunerating them (Calvin, 2017). In any organization activities are performed with the assistance of assets; machine, material, cash and above all men, who make use of these assets to create value, without them different assets will be futile, torpid and won't deliver anything (Xanthopoulou et al, 2009a). Accordingly, human asset is the best resource any organization can have and ought to be given the highest priority. Human resource gives premise to an organization to attain sustainable competitive advantage (Christensen, 2011). Since organizations are working in a dynamic and aggressive business environment, they are required to develop effective strategies for acquiring and retaining competent workforce (Baker et al, 2007). In recent era, human resource is thought to be the most imperative resource of any organization and to get the productive and powerful outcome from human asset, it has become crucial to influence their attitudes and behaviours positively that leads them contributing effectively in enhancing organizational productivity by enhancing their performance (Bauer et al, 2006). 
Previous research provides evidence that remuneration influences employees' performance and on the other hand it influences employees' attitudes or behaviours, but it is still unclear that whether such influence on their attitudes leads them towards their performance or whether performance is independent of their attitudes? Previous researches have investigated the impact of remuneration on performance (Xanthopoulou et al, 2009a; Detert et al, 2007; Peterson et al, 2011) and impact of remuneration on attitudes or behaviours of employees (Calvin, 2017; Baker et al, 2007; Bauer et al, 2006; Coyle and Conway, 2004) separately, but haven't investigated the fact that remuneration initially influences employees' attitudes that ultimately leads them towards their performance. Thus, current research fills this gap and investigates an indirect relation between remuneration and performance while incorporating employees' attitudes as a mediator. Such investigation contributes well not only in literature by identifying indirect relations of variables of interest but also a great contribution towards managers' understanding to improve their employees' performance so that they can make remuneration policies accordingly. They need to know remuneration doesn't directly influences employees' performance rather they need to influence employees' attitudes that will ultimately lead them towards their performance.

\section{Literature Review}

Organizations require exceptionally performing people, to have products and services they are specialised in, for attaining a competitive advantage, with a specific end goal to meet organizational objectives (Xanthopoulou et al, 2009b). High level performance and accomplishment of tasks can be a source of satisfaction along with sentiments of dominance and pride. Low performance and lack of accomplishment of objectives may be experienced as disappointing or even as individual failure (Coyle and Conway, 2004). Besides, performance if perceived by others inside the organization is frequently rewarded through financial and other aids. Performance is a noteworthy; although not the solitary essential requirement for future profession advancement and success in market (Masterson et al, 2000). Despite the fact of having exception, high performers are generally advanced easily within an organization and mostly have preferable profession openings comparative to low performers (Knippenberg et al, 2007).

\section{Remuneration}

Remuneration is generally observed as the aggregate income of an individual and may involve a range of discrete payments attained through different resources (Wayne et al, 2002). Remuneration is defined as reward or pay given to people for work done. The indicators of compensation include: fundamental pay, wages, wellbeing plans, pension plans, transport remittances, over time recompenses and responsibility stipends (Baker and Demerouti, 2007). Remuneration can likewise be alluded to as monetary or fiscal benefits in form of pay rates, compensation, rewards, impetuses, recompenses and benefits that is accumulated or given to a worker or a group of workers by the business (firm) because of benefits rendered by the employee(s), commitment to the organization or reward for work (Shields et al, 2015).

\section{Employee Attitude}

An attitude is a mental perspective. It is the way a man contemplates circumstances, and it eventually decides a man's conduct. In the work environment, workers can have either a positive or negative state of mind about work undertakings, services or products, colleagues or management, or the organization (Baker et al, 2007). Terrible attitudes result in indifference to routine tasks. Employees 
INTERNATIONAL JOURNAL OF ACADEMIC RESEARCH IN BUSINESS AND SOCIAL SCIENCES Vol. 8, No. 7, July 2018, E-ISSN: 2222-6990 @ 2018 HRMARS

are effortlessly fomented by minor issues. Assignments are finished at substandard levels (Peterson et al, 2011). Positive attitudes among employees make workdays more pleasant. Activities are performed to a higher standard and without objections. A case of a positive employee attitude happens when a worker sees a negative client service call as an opportunity to transform the narrative for the client from a terrible experience to a decent one (Crossman and Zaki, 2003). While managers can't change all determinants of negative attitudes in the working environment, there are approaches to advance positive ones. Ensuring workers have incentives that invigorate them generate inspirational attitudes (Xanthopoulou et al, 2009b).

\section{Employee Performance}

Employee performance can be defined as the job relevant activities anticipated from an employee and how well such activities are executed. Although there is no general and predominant theory about employees' execution (Calvin, 2017), thus the viability with which associations oversee, create and empower their employees is a significant cornerstone of organizational performance (Christensen et al, 2011). Hence, people management contributes significantly in performance (Xanthopoulou et al, 2009a). performance can be traced back to the attitudes of individuals on the shop floor. Employees work in certain ways and behave in a way that adds to (the objectives of) the association. If employees' performance doesn't add value, the organizations have no reason to exist (Bauer et al, 2006). This could be the value for clients, society and investors or for colleagues inside the association. Each worker makes an individual commitment to the execution of individual operational units and in this way to the whole association (Detert et al, 2007). On the off chance that the execution of a hierarchical unit or individual employee falls behind for a long time, this will prompt rearrangement or redundancy (Luthans et al, 2008). Especially in a situation in which rivalry is fiercer than ever, the significance of consistently performing is mounting (Shields et al, 2015). Employee performance is a crucial factor contributing directly to the performance of the company (Peterson et al, 2011). Companies today, with increased competition in the business arena, are keen to boost employee performance to boost their profitability, market reach and brand appreciation (Xanthopoulou et al, 2009b).

\section{Some Relevant Theories}

Following theories set the theoretical foundation of current study:

\section{Reinforcement and Expectancy Theory}

Reinforcement theory states that responses followed by rewards are more likely to recur in future. In other words, behaviours that result in receiving rewards are mostly repeated. Hence, the implication of remuneration is that high performance resulting in monetary rewards will ensure future performance (DeCremer et al, 2008). moreover, behaviours and attitudes of employees could be transformed if they receive rewards while exhibiting the desired behaviours or attitudes. A significant assumption of this theory is the regular delivery of rewards to make them the acquired right (Cropanzano et al, 2005). 
INTERNATIONAL JOURNAL OF ACADEMIC RESEARCH IN BUSINESS AND SOCIAL SCIENCES Vol. 8, No. 7, July 2018, E-ISSN: 2222-6990 @ 2018 HRMARS

\section{Equity Theory}

Equity theory states that employees expect same rewards for same inputs. In other words, employees when performing like other employees also desire same rewards as the others receive, thus the reward distribution becomes significant for the organizations (Wayne et al, 2002). the perceived equity of input-reward balance is significant in determine the way employees' behaviours, motivation and attitudes will transform. The theory mainly focuses on the equity of remuneration in terms of their pay structures (DeCremer et al, 2008). Employees perceptions about being treated by the organization becomes important to be considered by the organization. The inequity perceived by employees may result in declining productivity, increased absenteeism and higher turnovers (Cropanzano et al, 2005).

\section{Agency Theory}

Agency relationships are developed when one (the principal) hires the other (the agent) because of his/her specialised knowledge and skills. The theory centres around the disparate interests and objectives of the organization's partners and the way that compensation can be utilized to align these interests and objectives (Wayne et al, 2002). The remuneration owed to workers is the agency cost and traditionally employees expect higher cost while the business tries to limit it. Hence remuneration as wages or salaries can be settled upon based on the outcome or the conduct of employees (DeCremer et al, 2008).

\section{Remuneration and Employee Attitude}

Renumeration is a technique for promoting morale, increasing inspiration and encouraging team cohesion. Renumeration can propel workers to be more productive yet does not need to essentially be pay based (Xanthopoulou et al, 2009a). Renumeration can likewise be acclaim or acknowledgment. However, monetary renumeration can be powerful in long haul inspiration and profitability, for example, a raise or advancement (Calvin, 2017). Renumeration builds employees' confidence provided the rewards are perceived as equitable. In other words, giving incremental rewards considering which employee is the most prolific, the second most valuable and so on (Baker et al, 2007). General morale improves if every worker is conceded an opportunity to achieve an arrangement of objectives as opposed to defining one high objective that just a single employee can accomplish. It is trusted that compensation strategy represents one of the best speculations an organization makes (Christensen, 2011). Although a reasonable wage is the foundation of the legally binding and implied agreements amongst workers and businesses, the basic presumption is that money can directly impact conduct. Numerous representatives and supervisors trust that essentially expanding what individuals are paid will make them more roused, beneficial and steadfast (Bauer et al, 2006). The impact of compensation system is an essential ingredient in each association and that worker execution is a basic issue for some organizations, because of the need to pull in, rouse and retain the correct talent pool for a business to succeed (Coyle and Conway, 2004).

The need to attract, persuade, develop and hold employees is basic to any association's success today as far as making a domain in which workers feel genuinely engaged and connected to the association's objectives and goals and happy with their jobs has never been more essential (Masterson et al, 2000). The fundamental component in payment strategy is to guarantee that employees retain a decent execution level in the workplace as laborers need to trust that the compensation they gain is fair in connection to the work they do (Knippenberg et al, 2007). Furthermore, remuneration is one of the most grounded determinants of employee attitudes, 
INTERNATIONAL JOURNAL OF ACADEMIC RESEARCH IN BUSINESS AND SOCIAL SCIENCES Vol. 8, No. 7, July 2018, E-ISSN: 2222-6990 @ 2018 HRMARS

inspiration and behaviours (Peterson et al, 2011). However, the effect of pay on employees' activities and attitudes has concentrated on how pay is regulated (Wayne et al, 2002). Consistent with reinforcement and expectancy theories, when higher outcomes result in high pay increases, execution is strengthened and more prone to be rehashed later. A single change in pay is regularly a component of numerous elements including general soundness of the economy, financial capacity of the firm to raise compensation, association transactions, the need to hold an important individual or class of workers, and relative execution of a specific employee (Baker and Demerouti, 2007).

\section{Remuneration and Employee Performance}

Remuneration is considered as one of the most effective investments an organization can make. Although an impartial wage serves as a cornerstone for implied and contractual agreements between work force and employers (Xanthopoulou et al, 2009a), but the underlying presumption is that money could directly influence behaviour that leads towards performance (Christensen et al, 2011). Many individuals and managers believe that enhancing the level of payment will simply make individuals more motivated, loyal and productive (Detert et al, 2007). Organizations compensating their employees effectively are more likely to attain higher levels of productivity than others (Xanthopoulou et al, 2009b), because mostly remuneration is considered as a motivator by employees as well as managers (Shields et al, 2015). When employees are inspired by striking remunerations, their performance tremendously increases, and they are more likely to move towards attain organizational objectives without any resistance (Peterson et al, 2011). Employees' satisfaction depends on their expectations and how such expectations are fulfilled, hence favourably paid workers are mostly inspired to produce more while low payments leads to lower motivation which results in lower performance as well ((Crossman and Zaki, 2003).

Money although motivates employees by increasing their purchasing power and enabling them to fulfil their needs and wants but it is not the sole motivator to enhance employees' performance (Xanthopoulou et al, 2007), employees' may also want some non-monetary benefits like prestige, promotion, acknowledgment etc (Calvin, 2017). So, organizations are required not only to offer monetary benefits as remuneration but also acknowledging employees' contribution towards organizational goal achievement (Luthans et al, 2008). When individual goals are aligned with the goals of the organization, they are more satisfied, more motivated to contribute positively hence more productive for the organization (Malhotra et al, 2007).

\section{Conceptual Framework}

Based on the review of previous literature, following relationships are proposed by the study:

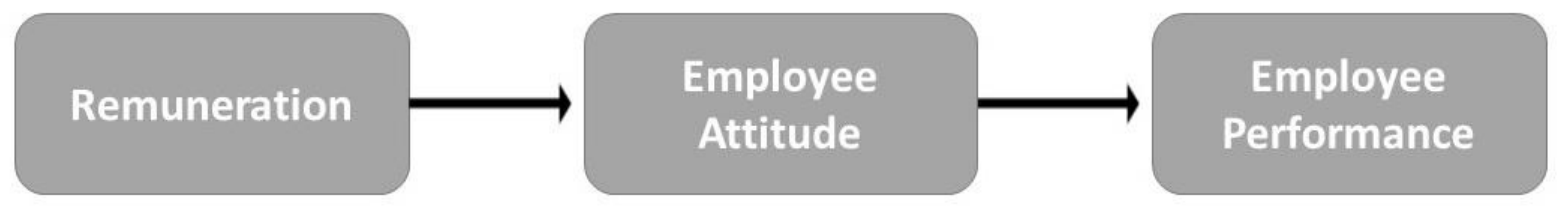

Figure 1: Proposed Model of Study

The above framework indicates that remuneration is an independent variable, employee performance is the dependant one, while employee attitude mediates the relationship between independent and dependent variables. 
INTERNATIONAL JOURNAL OF ACADEMIC RESEARCH IN BUSINESS AND SOCIAL SCIENCES

Vol. 8, No. 7, July 2018, E-ISSN: 2222-6990 @ 2018 HRMARS

\section{Hypothesis}

Following hypotheses are proposed to be tested in current study:

H1: Remuneration has significant influence on employee attitude.

$\mathrm{H}$ 2: Employee attitude has significant influence on employee performance.

H3: Remuneration has significant influence on employee performance.

H4: Employee attitude mediates the relationship between remuneration and employee performance.

\section{Data and Methodology}

A structured questionnaire adopted from Calvin (2017), with few modifications according to the requirements of current study, is distributed among four listed companies (Appendix 1: Table 1.1) of Amman Stock Exchange. Companies are selected from Textile, Leather and Clothing sector as manufacturing organizations incorporate manual and non-manual workers working on fixed remuneration as well as on daily, hourly or per unit basis. So, the views from all types of remuneration receiving individuals are captured. 50 employees from each company are selected randomly, so the total sample size is consisted of 200 respondents including both managerial and non-managerial employees. Valid responses are received from respondents, so all are included in the analysis. Respondents are asked about their remunerations, and if they get any extra type of remunerations or benefits based on their performance in the company. Moreover, they are asked if they feel motivated and have any changing attitudes because of receiving or not receiving the expected remunerations and benefits. How such remunerations arose their attitude towards work and how it influences their performance in the organization in future. Data collected through structured questionnaire is organized in SPSS. Quantitative data analysis techniques are implemented like descriptive statistics to provide information about respondents and structural equation modelling to find out the relationships among propose3d variables of study.

\section{Data Analysis and Results}

As a few changings are made in the adopted questionnaire, thus it is initially tested for its reliability through Cronbach's alpha. The alpha values of remuneration, employee attitude and employee performance are $0.85,0.78$ and 0.82 respectively, all having greater values than the minimum acceptable level of 0.7 , so the internal consistency of items is ensured. Descriptive statistics are as follows:

\begin{tabular}{|c|c|c|c|c|}
\hline \multirow{2}{*}{ Gender } & Male & Female & \\
\cline { 2 - 5 } & $56.6 \%$ & $43.4 \%$ & $40-50$ & \\
\hline \multirow{2}{*}{ Age } & $20-30$ & $30-40$ & $24.2 \%$ & \\
\cline { 2 - 5 } & $40.6 \%$ & $35.2 \%$ & $10-15$ & $>15$ \\
\hline \multirow{2}{*}{ Experience } & $1-5$ & $5-10$ & $26 \%$ & $17.9 \%$ \\
\cline { 2 - 5 } & $25.3 \%$ & $30.8 \%$ & & \\
\hline
\end{tabular}

Table 1: Demographics of Respondents

Structural equation modelling using AMOS is implemented to find out the relationships among variables in proposed model of study. Results of study are drawn based on Chi-square along with model fit indices like CMIN, NFI, GFI and RMSEA. The null hypothesis proposed by chi-square test is that the tested model is good fit. If null hypothesis is rejected than it means that the relationships proposed by researchers are not true and vice versa in case if null hypothesis is accepted. The chi- 
INTERNATIONAL JOURNAL OF ACADEMIC RESEARCH IN BUSINESS AND SOCIAL SCIENCES Vol. 8, No. 7, July 2018, E-ISSN: 2222-6990 @ 2018 HRMARS

square value for current tested model is 0.005 with a $p$ value of 0.956 , indicating that results are insignificant and null hypothesis could not be rejected. Hence the results of chi-square test indicate that the proposed relationships are good. But the results are further validated by other model fit indices as well. The values for model fit indices are as follows:

\begin{tabular}{|c|c|c|c|c|}
\hline Indices & CMIN & NFI & GFI & RMSEA \\
\hline Resulting Values & 0.005 & 0.91 & 0.94 & 0.000 \\
\hline Acceptable Range & $\begin{array}{c}\text { Smaller value } \\
\text { indicates good } \\
\text { fit }\end{array}$ & $\begin{array}{c}\text { Value closer to } \\
1 \text { indicates } \\
\text { goodness of fit }\end{array}$ & $\begin{array}{c}\text { Value closer to } \\
1 \text { indicates } \\
\text { goodness of fit }\end{array}$ & $\begin{array}{c}\text { Value closer to } \\
1 \text { indicates } \\
\text { badness of fit }\end{array}$ \\
\hline
\end{tabular}

Table 2: Results of Model Fit Indices

Table 2 illustrates the values of model fit indices as well as their acceptable ranges so that results can be drawn that the model is good fit or not. Comparing resulting values of indices with their acceptable ranges it is indicated that all indices result in goodness of fit of tested model. CMIN indicates goodness of fit of model if it has smaller value, and the value for current model is 0.005 , similarly GFI and NFI indicate goodness of fit of model if their values are closer to 1 and values for current model are GFI having 0.94 and NFI having 0.91 , hence indicating the goodness of fit of the tested model. in an opposite manner the RMSEA indicates badness of fit if having value closer to 1 , but the value for current tested model is 0.000 which indicates that the tested model is good fit. Hence the results of all model indices indicate that the proposed relationships are good. Further regression weights for tested model are as follows:

\begin{tabular}{|c|c|c|c|}
\hline & Estimate & S. E & P \\
\hline Employee Attitude $\ll<$ Remuneration & .643 & .061 & $* * *$ \\
\hline Employee Performance $<<<$ Employee Attitude & .176 & .039 & $* * *$ \\
\hline
\end{tabular}

Table 3: Regression Weights of Tested Model

Table 3 indicates the relationships among variables of study, indicating that significant relationships exist among remuneration and employee attitude and then among employee attitude and employee performance. according to the results obtained from empirical testing of the proposed model, the proposed hypotheses of study are all supported. The results for hypotheses are as follows:

\begin{tabular}{|l|c|}
\hline \multicolumn{1}{|c|}{ Hypothesis } & Result \\
\hline H1: Remuneration has significant influence on employee attitude. & Supported \\
\hline H2: Employee attitude has significant influence on employee performance. & Supported \\
\hline H3: Remuneration has significant influence on employee performance. & Supported \\
\hline $\begin{array}{l}\text { H4: Employee attitude mediates the relationship between remuneration and } \\
\text { employee }\end{array}$ & Supported \\
\hline
\end{tabular}

Table 4: Hypotheses Results

\section{Key Findings \& Conclusion}

Current study investigated the impact of remuneration on employee performance while investigating the mediating role of employee attitude as well. Empirical investigation of proposed model indicates significant relationships among variables of study and model fit indices validate the proposed relationships as true. It is found that remuneration has significant influence on employee 
INTERNATIONAL JOURNAL OF ACADEMIC RESEARCH IN BUSINESS AND SOCIAL SCIENCES Vol. 8, No. 7, July 2018, E-ISSN: 2222-6990 @ 2018 HRMARS

performance, but employees' attitude mediates the relationship. Thus, it is concluded that remuneration influences employees' attitude that ultimately influences employee's performance. So, organizations should focus on their remuneration plans, because having satisfactory remunerations, employees would have positive attitudes towards their jobs and resulting in an increased level of performance. Employees should be offered remuneration in monetary as well as other forms so that employees are motivated to have positive attitudes to contribute positively towards organizational goal achievement.

\section{Applied Implications}

Current study has significant implications not only for a specific sector but also for all manufacturing firms as it highlights the importance of remuneration for employees' performance and how firms could get higher levels of productivity by inspiring employees' attitudes through remunerations. Thus, organizations should focus on their remuneration systems to have higher levels of productivity.

\section{Limitations and Future Recommendations}

Current study is limited to a specific sector while results may change incorporating some other sectors as well. Moreover, it only focused on the manufacturing firms while similar study could be conducted for service firms and investigating whether remuneration also have significant influence on employees' performance in services firms or not?

\section{Acknowledgement}

After the main body of paper please insert acknowledgement of all those (personals or institutions) that have helped in conducting this study.

\section{Corresponding Author}

Insert complete information of corresponding author including name, affiliation, country, email ID, Address.

\section{References}

Amman Stock Exchange. "Listed Equities". Retrieved from: https://www.ase.com.jo/en/equities [June 13, 2018]. 2018.

Bakker, A. B. \& Demerouti, E. "The job demands-resources model: State of the art". Journal of Managerial Psychology. Volume. 22. Pages. 309-328, 2007.

Bakker, A. B., Hakanen, J. J., Demerouti, E. \& Xanthopoulou, D. "Job resources boost work engagement, particularly when job demands are high". Journal of Applied Psychology. Volume. 99. Pages. 274-284, 2007.

Bauer, T. N., Erdogan, B., Liden, R. C. \& Wayen, S. J. “A Longitudinal Study of the Moderating Role of Extraversion: Leader-Member Exchange, Performance, and Turnover During New Executive Development. Journal of Applied Psychology. Volume. 91. Pages. 298-310, 2006.

Calvin, O. Y. 2017. The Impact of Remuneration on Employees' Performance (A Study of Abdul Gusau Polytechnic, Talata-Mafara and State College of Education Maru, Zamfara State). Arabian Journal of Business and Management Review. Nigerian Chapter. Vol. 4. No. 2. Pp. 34-43.

Christensen, A. L. "Linking Ethical Leadership to Employee Performance: The Role of Leader Member Exchange, Self-Efficacy, and Organizational Identification". Organizational Behaviour and Human Decision Process. Volume. 115. Number. 2. Pages. 204-213, 2011. 
INTERNATIONAL JOURNAL OF ACADEMIC RESEARCH IN BUSINESS AND SOCIAL SCIENCES

Vol. 8, No. 7, July 2018, E-ISSN: 2222-6990 @ 2018 HRMARS

Coyle, S. J. A. \& Conway, N. "The Employment Relationship through The Lens of Social Exchange". In Shapiro, J. A. M., Shore, L. M. Taylor, S. M. \& Tetrick, L. (Eds.). The Employment Relationship: Examining Psychological and Contextual Perspectives. Oxford, UK. Oxford University Press. Pages. 528, 2004.

Cropanzano, R. \& Mitchell, M. S. "Social exchange theory: An interdisciplinary review". Journal of Management. Volume. 31. Pages. 874-900, 2005.

Cropanzano, R., Bowen, D. E. \& Gilliland, S. W. “The management of organizational justice”. Academy of Management Perspectives. Volume. 21. Pages. 34-48, 2007.

Crossman, A. \& Zaki, A. "Job Satisfaction and Employee Performance of Lebanese Banking Staff". Journal of Managerial Psychology. Volume. 18. Issue. 4. Pages. 368-376, 2003.

DeCremer, D., Brebels, L. \& Sedikides, C. "Being Uncertain about What? Procedural Fairness Effects as a Function of General Uncertainty and Belongingness Uncertainty". Journal of Experimental Social Psychology. Volume. 44. Pages. 1520-1525, 2008.

Detert, J. R., Trevino, L. K., Burris, E. R. \& Andiappan, M. “Managerial modes of influence and counterproductivity in organizations: A longitudinal business unit-level investigation". Journal of Applied Psychology. Volume. 92. Pages. 993-1005, 2007.

Knippenberg, D., Dick, R. \& Tavares, S. "Social identity and social exchange: Identification, support, and withdrawal from the job". Journal of Applied Social Psychology. Volume. 37. Pages. 457-477, 2007.

Luthans, F., Norman, S. M., Avolio, B. J. \& Avey, J. B. "The Mediating Role of Psychological Capital in The Supportive Organizational Climate Employee Performance Relationship". Journal of Organizational Behaviour. Volume. 29. Pages. 219-238, 2008.

Malhotra, N., Budhwar, P. \& Prowse, P. "Linking Rewards to Commitment: An Empirical Investigation of Four UK Call Centres". The International Journal of Human Resource Management. Volume. 18. Number. 12. Pages. 2095-2128, 2007.

Masterson, S. S., Lewis, K., Goldman, B. M. \& Taylor, M. S. "Integrating justice and social exchange: The differing effects of fair procedures and treatment on work relationships". Academy of Management Journal. Volume. 43. Pages. 738-748, 2000.

Peterson, S. J., Luthans, F., Avolio, B. J., Walumbwa, F. O. \& Zhang, Z. "Psychological Capital and Employee Performance: A Latent Growth Modelling Approach". Personnel Psychology. Volume. 64. Issue. 2. Pages. 287-315, 2011.

Shields, J., Brown, M., Kaine, S., Samuel, C., Samardzic, A., McLean, P., Johns, R. Leary, P., Plimmer, G. \& Robinson, J. “Managing Employee Performance \& Reward: Concepts, Practices, Strategies". $2^{\text {nd }}$ Edition. Cambridge University Press. London. 2015.

Wayne, S. J., Shore, L. M., Bommer, W. H. \& Tetrick, L. E. "The role of fair treatment and rewards in perceptions of organizational support and leader-member exchange". Journal of Applied Psychology. Volume. 87. Pages. 590-598, 2002.

Xanthopoulou, D., Bakker, A. B., Demerouti, E. \& Schaufeli, W. B. "The role of personal resources in the job demands resources model". International Journal of Stress Management. Volume. 14. Pages. 121-141, 2007.

Xanthopoulou, D., Bakker, A. B., Demerouti, E. \& Schaufeli, W. B. "Work engagement and financial returns: A diary study on the role of job and personal resources". Journal of Occupational and Organizational Psychology. Volume. 82. Pages. 183-200, 2009a. 
INTERNATIONAL JOURNAL OF ACADEMIC RESEARCH IN BUSINESS AND SOCIAL SCIENCES

Vol. 8, No. 7, July 2018, E-ISSN: 2222-6990 @ 2018 HRMARS

Xanthopoulou, D., Bakker, A. B., Demerouti, E. \& Schaufeli, W. B. "Reciprocal relationships between job resources, personal resources, and work engagement". Journal of Vocational Behaviour. Volume. 74. Pages. 235-244, 2009b.

\section{Appendix}

\begin{tabular}{|c|c|}
\hline & Textile, Leather and Clothing Sector Amman Stock Exchange \\
\hline 1 & Century Investment Group \\
\hline 2 & The Jordan worsted mills \\
\hline 3 & El-Zay ready wear manufacturing \\
\hline 4 & Arab Weavers union company plc. \\
\hline
\end{tabular}

Table 1.1: Name of Companies (Source: Amman Stock Exchange, 2018) 